\title{
Preliminary Investigation on Crop Growth, Physiology, and Yield of Rice under Partial Root-Zone Irrigation
}

\author{
Theivasigamani Parthasarathi $\mathbb{D},{ }^{1}$ A. R. Nirmal kumar $\mathbb{D}^{2}$ and Koothan Vanitha $\mathbb{D}^{3}$ \\ ${ }^{1}$ Crop Physiology and Genomics Lab, VIT School of Agricultural Innovations and Advanced Learning (VAIAL), \\ Vellore Institute of Technology, Vellore, Tamil Nadu, India \\ ${ }^{2}$ Regional Agricultural Research Station (RARS), Tirupati, India \\ ${ }^{3}$ Department of Crop Physiology, Tamil Nadu Agricultural University, Coimbatore, Tamil Nadu, India
}

Correspondence should be addressed to Theivasigamani Parthasarathi; tparthasarathicrp@gmail.com

Received 7 April 2020; Revised 18 October 2020; Accepted 3 November 2020; Published 24 November 2020

Academic Editor: Mathias N. Andersen

Copyright (C) 2020 Theivasigamani Parthasarathi et al. This is an open access article distributed under the Creative Commons Attribution License, which permits unrestricted use, distribution, and reproduction in any medium, provided the original work is properly cited.

\begin{abstract}
Rice is a staple food predominantly consumed by more than half of the global population. Water deficit is a crucial threat to produce rice globally. Prevailing water-saving techniques for rice can reduce water inputs but are not widely adopted due to the high yield penalty. Partial root-zone irrigation (PRI) is an innovative water-saving technique that allows simultaneous wet and dry areas within the root zone. We hypothesized that optimized PRI improves the water use and reduces the yield penalty of rice. A split root experiment was conducted on rice grown in pots with six defined PRI treatments, that is, $\mathrm{PRI}_{1}, \mathrm{PRI}_{2}, \mathrm{PRI}_{3}, \mathrm{PRI}_{4}, \mathrm{PRI}_{5}$, and $\mathrm{PRI}_{6}$. Half of the root system was wetted and alternated between halves with one- $\left(\mathrm{PRI}_{1}\right)$, two- $\left(\mathrm{PRI}_{2}\right)$, three- $\left(\mathrm{PRI}_{3}\right)$, four$\left(\mathrm{PRI}_{4}\right)$, five- $\left(\mathrm{PRI}_{5}\right)$, and six- $\left(\mathrm{PRI}_{6}\right)$ day intervals. Conventionally irrigated rice plants where the whole root zone of rice was wetted and grown in the nonsplit pot were maintained and considered as control. Control and PRI treatments were irrigated based on $100 \%$ potential evapotranspiration demand $(\mathrm{ETc})$. In particular, one PRI treatment $\left(\mathrm{PRI}_{3}\right)$ showed a remarkable increase in active roots and leaf photosynthesis $\left(P_{N}\right)$ by wet and dry cycles within the root zone. Distinctive shoot responses of rice under PRI indicated enriched physiological responses for superior water productivity. The third-day-interval partial root-zone irrigation $\left(\mathrm{PRI}_{3}\right)$ and conventional irrigation had similar leaf water potential $\left(\Psi_{\text {leaf }}\right)$, while $\mathrm{PRI}_{3}$ had higher grain yield than conventional treatment and higher root surface area that may have compensated for the moderate level of stress in PRI. The finding that PRI scheduled at three-day intervals $\left(\mathrm{PRI}_{3}\right)$ was superior to conventional irrigation for a single rice plant is promising and needs to be tested and adapted to field conditions.
\end{abstract}

\section{Introduction}

Improvement in growth per unit of water used, i.e., in water use efficiency (WUE), is an ultimate goal in many agricultural systems. Shortage in irrigation water constraints crop production worldwide [1]. Specifically, Asian rice production is increasingly constrained by water shortage [2]. To confront this, it is necessary to develop water-saving measures by producing more crop per drop. Deficit irrigation (DI) and alternate partial root-zone irrigation- (PRI-) water-saving irrigation strategies are widely used in arid and semiarid regions [3]. Deficit irrigation supplied less water than crop evapotranspiration, and it is predominant in all parts of the world due to a reduction in water availability [4]. Partial root-zone irrigation (PRI) is for both wet and dry regions, within the root zone. PRI is an advanced form of DI; it involves irrigating one part of the root zone, leaving the other part dry to a predetermined level before the next irrigation [5].

Consequently, DI and PRI treatments are expected to trigger different water-deficit stress mechanisms, resulting in different plant physiological and growth responses $[6,7]$. In recent years, to illustrate the mechanisms underlying the agronomic advantage of PRI over DI, several studies have 
been carried out to reveal the differences in the two types of irrigation by influencing abscisic acid (ABA) signaling $[5,8]$, root growth $[9,10]$, and crop nitrogen nutrition [11-13].

The partial root-zone watering of each side of the root system alters the root-sourced ABA signaling, to regulate the growth and water efficacy of the plant [14]. PRI has proven to be promising in many crops, including grapevine [14], oilseed rape [15], maize [16], sunflower [17], tomato [18], wheat [19], olive [20], and potato [21]. Previous studies revealed that PRI plants possess significantly larger root systems and greater nitrogen accumulation $[8,9,12]$, and all of these responses might have contributed to the higher WUE in plants $[16,22]$. From this constructed effect of PRI, it is probable that PRI may be promising for rice.

Therefore, it was hypothesized that PRI improves the water use and yield of rice. Thus, with this background, a split root experiment was designed and performed in rice crops with different PRI treatments. The objectives of the present study were to assess the PRI on changes in morphophysiology, leaf gas exchange, and chlorophyll fluorescence and to study the effect of PRI on grain yield and water productivity.

\section{Materials and Methods}

The partial root-zone irrigation (PRI) experiment in rice was conducted at VIT School of Agricultural Innovations and Advanced Learning, Vellore Institute of Technology, Vellore, Tamil Nadu, India. Thirty pots with split root chambers were constructed by taking standard $4-\mathrm{L}$ pots $(30 \mathrm{~cm}$ height plastic pots with a diameter of $18 \mathrm{~cm}$ bottom and $21 \mathrm{~cm}$ top) and splitting them up to $25 \mathrm{~cm}$ from the bottom to top (Figure 1(a)). Two heavy plastic sheets were pulled taut within the split and attached to the pot with duct tape. By filling one part of the pot with water, it was confirmed that water could not leak into the other part of the pot. A horizontal slit was made near the tops of the plastic sheets. The pot mixtures were prepared in a $2: 1: 1$ proportion of wetland soil, farmyard manure, and sand, respectively, and filled in the pots to a depth of $24 \mathrm{~cm}$. The variety PMK $(R) 3$ (Parentage UPLRI $7 \times$ CO 43 ) seeds were sown in coir pith and vermicompost filled pots for root development. Fifteenday-old seedlings were taken, and two seedlings per pot were transplanted in the split pot. The seedlings were transplanted; half of the roots were passed through one side and the other half roots into the next side (Figure 1(a)). The stem was placed on the separator and was tied to a stake for support. Both sides of the pots were watered continuously for four days to ease transplantation shock and fertilized with complex fertilizer $(19: 19: 19 \mathrm{NPK})$ at $1 \mathrm{~g} \cdot \mathrm{L}^{-1}$ twice a week.
The experiment comprised six partial root-zone irrigation (PRI) treatments and control (conventional irrigation) (Figure 1(b)). Partial root-zone irrigation (PRI), defined as partial or one side of the root system, was wetted, and rewetting was given to another side at regular intervals. The treatment details are as follows: $\mathrm{PRI}_{1}$-PRI at alternate days; $\mathrm{PRI}_{2}$-PRI at $2^{\text {nd }}$-day intervals; $\mathrm{PRI}_{3}$-PRI at $3^{\text {rd }}$-day intervals; $\mathrm{PRI}_{4}$-PRI at $4^{\text {th }}$-day intervals; $\mathrm{PRI}_{5}$-PRI at $5^{\text {th }}$-day intervals; $\mathrm{PRI}_{6}$-PRI at $6^{\text {th }}$-day intervals and control-conventional irrigation. The PRI treatments were scheduled at respective day intervals based on reference evapotranspiration (ETo) (open pan evaporation measurement) and crop factor $(K c)$. The irrigation was scheduled based on $100 \%$ pan evaporation (PE). The potential evapotranspiration was calculated using the following formula:

$$
\mathrm{ET}_{c}=K_{c}^{*} \mathrm{ET}_{o}
$$

where ETo is the reference evapotranspiration calculated from the Penman-Monteith equation [23], and $K_{c}$ is the crop factor.

The PRI treatments were started ten days after transplantation. The volume of water was irrigated to one-half of the root system and then drying halves of the root zone were alternated at different irrigation intervals (one to six day$\mathrm{s} \sim \mathrm{PRI}_{1}$ to $\mathrm{PRI}_{6}$ ). The control plants received full irrigation with $100 \% \mathrm{ET}_{c}$ on both sides of the root system. To maintain an accurate water supply, the volume of water in all the treatments was accounted for and irrigated manually. The experiment was repeated twice with four replications, and the split pots were arranged on a completely randomized design in a controlled environment for the entire experiment.

Leaf gas exchange measurements were performed using an infrared gas (IRGA) system (Model LI-6400, LiCor Inc., Lincoln, Nebraska, USA). The measurements were recorded on the uppermost fully expanded leaves (active central leaves positioned at the third leaf from the top) at 45 and 65 DAT. Leaves were inserted in a $3 \mathrm{~cm}^{2}$ leaf chamber and exposed to PPFD $1500 \mu \mathrm{mol}$ photons $\mathrm{m}^{-2} \cdot \mathrm{s}^{-1}$, and relative humidity was set at 50-55\%, respectively. Gas exchange parameters were computed using the equations of [24]. The parameters recorded were photosynthetic rate $\left(P_{N}: \mu \mathrm{mol} \mathrm{CO} \mathrm{CO}^{-2} \cdot \mathrm{s}^{-1}\right)$,

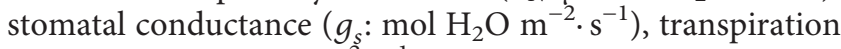
rate $\left(T_{r}: \mathrm{mmol} \cdot \mathrm{H}_{2} \mathrm{O} \cdot \mathrm{m}^{-2} \cdot \mathrm{s}^{-1}\right)$, and substomatal $\mathrm{CO}_{2}$ concentration $\left(C_{i}: \mu \mathrm{mol} \cdot \mathrm{CO}_{2} \cdot \mathrm{mol}^{-1}\right)$. The intrinsic water use efficiency and instantaneous water use efficiency were determined according to the method of Kannan and Venkataramanan [25].

$$
\text { intrinsic WUE }=\left\{\text { leaf photosynthetic rate }\left(P_{N}\right) / \text { stomatal conductance }\left(g_{s}\right)\right\}
$$

instantaneous WUE $=\left\{\right.$ leaf photosynthetic rate $\left(P_{N}\right) /$ transpiration rate $\left.\left(T_{r}\right)\right\}$. 


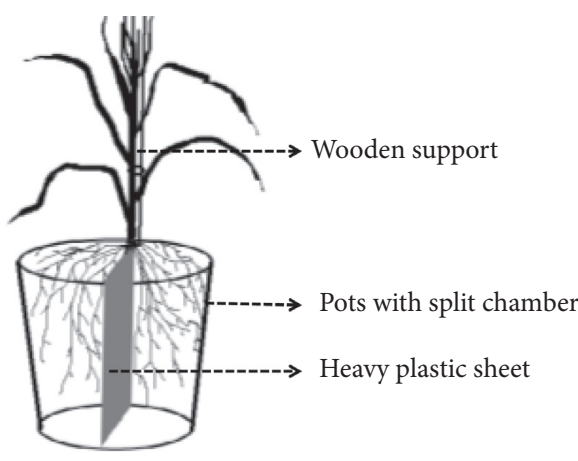

PRI 1

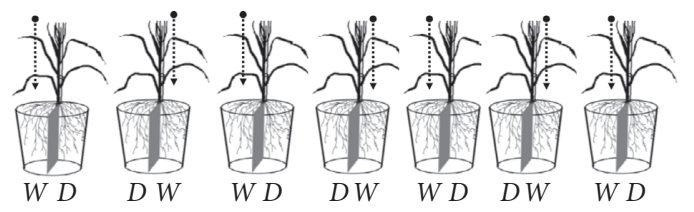

PRI 2

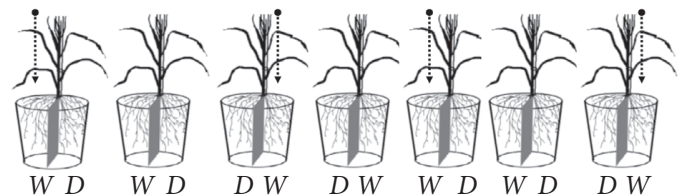

PRI 3
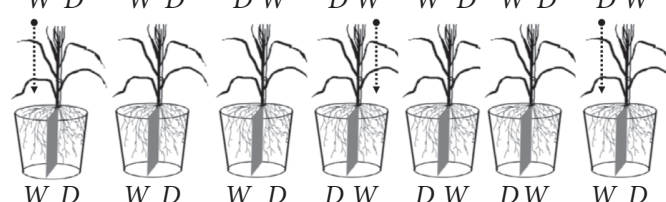

RI 4
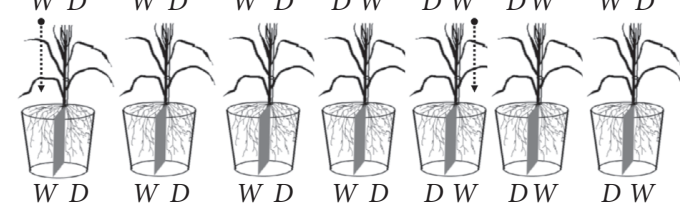

RI 5
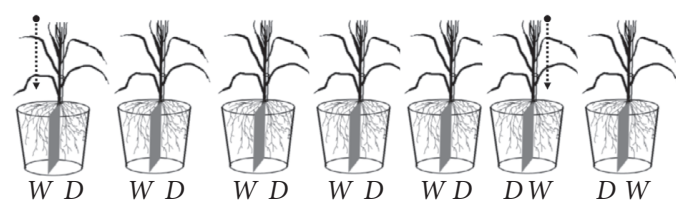

PRI 6
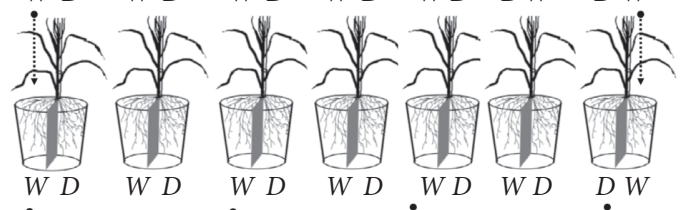

Control
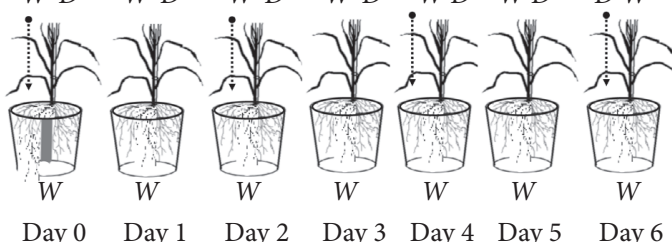

Irrigation

Wet $W$

Dry $D$

(a)

(b)

FIgURE 1: Schematic view of the split root pot (a) and irrigation treatments (b) in rice.

Chlorophyll fluorescence parameters were measured based on the dark-adapted and light-adapted fluorescence conditions. Fluorescence measurements were recorded on uppermost fully expanded leaves at 45 and 65 DAT. The quantum efficiency of PS II (ФPS2) was calculated according to the method of Genty et al. [26].

Chlorophyll a, b, and total content were estimated in a fully expanded young leaf during flowering (65 DAT) and expressed in $\mathrm{mg}^{-1} \mathrm{~g}^{-1}$ fresh weight [27]. The leaf water potential $\left(\Psi_{\text {leaf }}\right)$ was measured at the same midday using a Scholander-type pressure chamber (Soil Moisture Equipment Corp., Santa Barbara, CA, USA, and units expressed in $\mathrm{MPa})$.
Root morphological parameters were determined using a flatbed image scanner (Epson Expression 10000XL; Epson America, Inc., San Jose, CA, USA) and measured with WinRHIZO (WinRHIZO v. 2009b; Regent Instruments, Montreal, QC, Canada) software. At the end of the experiment, the entire root system was cut, evenly distributed, and scanned. Plant height, number of tillers, leaf area, and dry matter accumulation were recorded at the end of the experiment. The total water applied (mm) was accounted for; water productivity of the crop was estimated and expressed as $\mathrm{kg}$ grains $\mathrm{m}^{-3}$ of water.

A randomized design (CRD) analysis was carried out on various parameters as per the procedure suggested by 


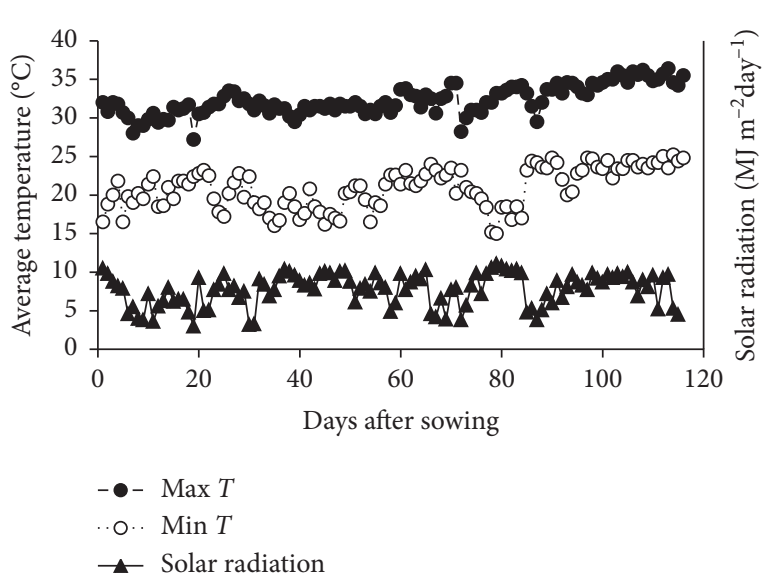

(a)

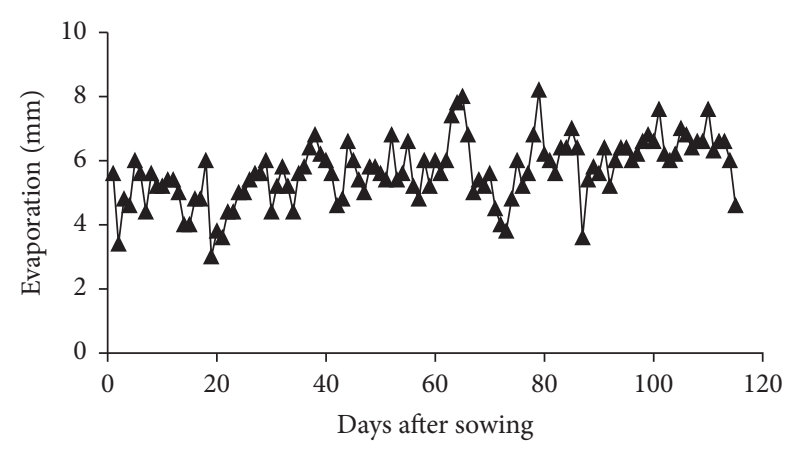

(b)

FIGURE 2: Daily maximum, minimum temperature, solar radiation (a), and evaporation rate (b) prevailed during the experiment (summer, 2019).

Gomez and Gomez [28]. The treatment differences were found to be significant and critical differences were determined at a 5\% probability level. Analysis of variance (ANOVA) was carried out using JMP, 2007 (SAS Institute, Cary, NC) software, and appropriate standard errors of the means (SEM) and LSD at $P=0.05$ were calculated.

\section{Results}

The temperature, solar radiation, and evaporation during the experiment (summer season 2019) are shown in Figure 2. The mean maximum and minimum temperatures were $32.9^{\circ} \mathrm{C}$ and $21.5^{\circ} \mathrm{C}$, respectively. The mean radiation of sunshine and evaporation was $7.8 \mathrm{MJ} \mathrm{m}^{-2} \cdot \mathrm{d}^{-1}$ and $5.8 \mathrm{~mm}$ prevailed during the cropping period, respectively. Total rainfall of $81 \mathrm{~mm}$ was experienced during the experimental period. Conventional irrigation was supplied with a total of $686 \mathrm{~mm}$ (irrigation and rainfall). Compared to conventional irrigation, there was an increase of $36.2 \%, 48.2 \%, 54.8 \%$, $57.7 \%, 60.6 \%$, and $62.5 \%$ for $\mathrm{PRI}_{1}, \mathrm{PRI}_{2}, \mathrm{PRI}_{3}, \mathrm{PRI}_{4}, \mathrm{PRI}_{5}$, and $\mathrm{PRI}_{6}$, respectively (Table 1 ).

The morphological changes in rice indicated that the PRI treatments were significantly different from conventional irrigation in terms of growth parameters (Table 2). PRI treatments significantly improved the plant height by $16.1 \%$ at $\mathrm{PRI}_{3}$ and decreased by $10.3 \%$ at $\mathrm{PRI}_{6}$ compared with conventional irrigation. The PRI treatments on rice showed a significant increase in root attributes at short PRI intervals $\left(\mathrm{PRI}_{1}\right.$ to $\mathrm{PRI}_{3}$ ) and reduction from $\mathrm{PRI}_{4}$ to $\mathrm{PRI}_{6}$. Total root length, root surface area, and root volume of rice were significantly increased in $\mathrm{PRI}_{1}$ and $\mathrm{PRI}_{3}$ treatments than in conventional irrigation. The root diameter of $\mathrm{PRI}_{3}$ treatment was $20.2 \%$ smaller than that of conventional irrigation in the root zone (Table 3). Among the PRI treatments, $\mathrm{PRI}_{3}$ had increased plant height, tiller number, leaf area, total dry matter accumulation (root and shoot dry mass), and better shoot: root ratio compared to conventional irrigation (Table 4).

Rice leaf gas exchange, photosystem efficiency, and water use efficiency were significantly higher in PRI treatments when compared to conventional irrigation (Figures 3 and 4). Among the PRI treatments, $\mathrm{PRI}_{3}$ increased the leaf photosynthetic rate $\left(P_{N}\right)$, stomatal conductance $\left(g_{s}\right)$, and transpiration rate $\left(T_{r}\right)$ at 45 and 65 DAT (days after transplantation). Reduction in leaf $P_{N}, g_{s}$, and $T_{r}$ was due to partial stomatal closure in $\mathrm{PRI}_{4}$ to $\mathrm{PRI}_{6}$ treatments (Figure 3). Photosystem efficiency (PSII) of rice was found to be significant by adopting PRI treatments at shorter intervals $\left(\mathrm{PRI}_{1}\right.$ to $\mathrm{PRI}_{3}$ ) due to frequent rewetting of the partial root system at 45 and 65 DAT. The rice water use efficiency (instantaneous) was significantly increased by $19.4 \%$ in $\mathrm{PRI}_{3}$ treatment over the conventional irrigation at $45 \mathrm{DAT}$ (Figure 4). The intrinsic WUE of PRI treatments showed a significant reduction over conventional treatment at 45 DAT. However, WUE showed less variation in $\mathrm{PRI}_{3}, \mathrm{PRI}_{2}$, and $\mathrm{PRI}_{1}$ treatments $\left(45 \mu \mathrm{mol} \mathrm{CO} \mathrm{mol}^{-1}\right.$ water $)$ at $65 \mathrm{DAT}$. The canopy temperature was significantly reduced $(P=0.05)$ to $6.6 \%$ at short-interval $\mathrm{PRI}\left(\mathrm{PRI}_{1}\right.$ to $\left.\mathrm{PRI}_{3}\right)$ treatments $\left(26^{\circ} \mathrm{C}\right)$ than the conventional irrigation $\left(28^{\circ} \mathrm{C}\right)$.

Leaf chlorophyll content was reduced in PRI treatments during the flowering phase (Figures 5 and 6). Among the PRI treatments, $\mathrm{PRI}_{3}$ maintained significantly $(P=0.05)$ more chlorophyll a $\left(1.8 \mathrm{mg} \cdot \mathrm{g}^{-1}\right), \quad \mathrm{b}\left(0.6 \mathrm{mg} \cdot \mathrm{g}^{-1}\right)$, and total $\left(2.2 \mathrm{mg} \cdot \mathrm{g}^{-1}\right)$ content (Figure 5). Similar treatments showed a better chlorophyll a/b ratio (2.9) than the rest. Rice leaf water potential was significantly reduced in $\mathrm{PRI}_{4}, \mathrm{PRI}_{5}$, and $\mathrm{PRI}_{6}$ treatments compared to conventional irrigation (Figure 6). Compared to conventional irrigation, changes in leaf water potential were not significant when $\mathrm{PRI}_{1}$ was adopted for $\mathrm{PRI}_{3}$ treatments.

The yield components were recorded to be significantly higher in PRI treatments at shorter cycles (Table 5). The 
TABLE 1: Rainfall and total water supply (irrigation plus rainfall) of PMK $(R) 3$ rice by split root experiment.

\begin{tabular}{lcccc}
\hline Irrigation treatments & Irrigated water $(\mathrm{mm})$ & Rainfall $(\mathrm{mm})$ & Total water applied $(\mathrm{mm})$ & Water saving relative to control $(\mathrm{mm})$ \\
\hline $\mathrm{PRI}_{1}$ & 356 & 81 & 437 & 249 \\
$\mathrm{PRI}_{2}$ & 274 & 81 & 355 & 331 \\
$\mathrm{PRI}_{3}$ & 229 & 81 & 310 & 376 \\
$\mathrm{PRI}_{4}$ & 209 & 81 & 290 & 396 \\
$\mathrm{PRI}_{5}$ & 189 & 81 & 270 & 416 \\
$\mathrm{PRI}_{6}$ & 176 & 81 & 257 & 429 \\
Control & 605 & 81 & 686 & 0 \\
Mean & 291 & 81 & 372 & - \\
\hline
\end{tabular}

Increment in water saving is expressed at different partial root-zone irrigation treatments over the conventional irrigation.

TABle 2: Plant growth measurements of rice under the split root experiment.

\begin{tabular}{|c|c|c|c|c|}
\hline $\begin{array}{l}\text { Irrigation } \\
\text { treatments }\end{array}$ & $\begin{array}{l}\text { Plant height }(\mathrm{cm} \\
\left.\text { plant }^{-1}\right)\end{array}$ & $\begin{array}{l}\text { Tiller number (number } \\
\text { plant }^{-1} \text { ) }\end{array}$ & $\begin{array}{l}\text { Leaf area }\left(\mathrm{cm}^{2}\right. \\
\left.\text { plant }^{-1}\right)\end{array}$ & $\begin{array}{l}\text { Total dry matter accumulation ( } \mathrm{g} \\
\text { plant }^{-1} \text { ) }\end{array}$ \\
\hline $\mathrm{PRI}_{1}$ & $81.0 \pm 1.02^{\mathrm{c}}$ & $15 \pm 0.20^{\mathrm{b}}$ & $4200 \pm 70.6^{\mathrm{ab}}$ & $74.2 \pm 0.63^{\mathrm{c}}$ \\
\hline $\mathrm{PRI}_{2}$ & $86.5 \pm 1.09^{\mathrm{b}}$ & $14 \pm 0.13^{c}$ & $3972 \pm 152.2^{\mathrm{b}}$ & $78.8 \pm 0.67^{\mathrm{b}}$ \\
\hline $\mathrm{PRI}_{3}$ & $90.2 \pm 1.14^{\mathrm{a}}$ & $16 \pm 0.15^{\mathrm{a}}$ & $4484 \pm 93.5^{\mathrm{a}}$ & $89.1 \pm 0.75^{\mathrm{a}}$ \\
\hline $\mathrm{PRI}_{4}$ & $73.8 \pm 0.93^{\mathrm{d}}$ & $12 \pm 0.13^{\mathrm{d}}$ & $3226 \pm 93.3^{c}$ & $68.5 \pm 0.58^{\mathrm{d}}$ \\
\hline $\mathrm{PRI}_{5}$ & $70.2 \pm 0.89^{\mathrm{e}}$ & $10 \pm 0.12^{\mathrm{e}}$ & $2910 \pm 116.1^{\mathrm{d}}$ & $66.3 \pm 0.56^{\mathrm{e}}$ \\
\hline $\mathrm{PRI}_{6}$ & $67.9 \pm 0.86^{\mathrm{e}}$ & $7 \pm 0.11^{\mathrm{f}}$ & $2541 \pm 105.9^{\mathrm{e}}$ & $57.6 \pm 0.49^{\mathrm{f}}$ \\
\hline Control & $75.7 \pm 0.96^{\mathrm{d}}$ & $14 \pm 0.16^{c}$ & $3908 \pm 91.5^{\mathrm{b}}$ & $69.9 \pm 0.59^{d}$ \\
\hline Mean & 77.9 & 12.5 & 3605.8 & 72.1 \\
\hline SE & 0.149 & 0.059 & 161.6 & 0.120 \\
\hline $\mathrm{CD}(0.05)$ & $0.312^{* *}$ & $0.123 * *$ & $339.6 * *$ & $0.251 * *$ \\
\hline $\mathrm{CD}(0.01)$ & 0.428 & 0.169 & 465.2 & 0.344 \\
\hline
\end{tabular}

Changes in plant height, tiller numbers, leaf area, and total dry mass accumulation are shown at different partial root-zone irrigation treatments. Values indicate the mean of eight plants; \pm indicates standard error of the mean; letters indicate significant differences $(P<0.05)$ among means according to Student's $t$-test. CD represents the critical difference at $95 \%(0.05)$ and $99 \%(0.01)$ confidence limit.

TABle 3: Root traits changes of PMK $(R) 3$ rice by split root experiment.

\begin{tabular}{|c|c|c|c|c|}
\hline Irrigation treatments & Total root length $\left(\mathrm{m} \mathrm{hill}{ }^{-1}\right)$ & Root surface area $\left(\mathrm{cm}^{2}\right.$ hill $\left.^{-1}\right)$ & Average root diameter $(\mathrm{mm})$ & Root volume $\left(\mathrm{cm}^{3}\right.$ hill $\left.^{-1}\right)$ \\
\hline $\mathrm{PRI}_{1}$ & $4.71 \pm 0.16^{\mathrm{ab}}$ & $1287 \pm 61.1^{\mathrm{b}}$ & $0.95 \pm 0.03^{\mathrm{b}}$ & $0.58 \pm 0.02^{\mathrm{a}}$ \\
\hline $\mathrm{PRI}_{2}$ & $4.26 \pm 0.10^{\mathrm{bc}}$ & $1191 \pm 47.0^{\mathrm{b}}$ & $0.91 \pm 0.02^{\mathrm{b}}$ & $0.56 \pm 0.01^{\mathrm{a}}$ \\
\hline $\mathrm{PRI}_{3}$ & $4.89 \pm 0.12^{\mathrm{ab}}$ & $1455 \pm 82.5^{\mathrm{a}}$ & $0.83 \pm 0.02^{\mathrm{b}}$ & $0.60 \pm 0.02^{\mathrm{a}}$ \\
\hline $\mathrm{PRI}_{4}$ & $4.03 \pm 0.13^{c}$ & $931 \pm 49.7^{\mathrm{c}}$ & $0.74 \pm 0.01^{\mathrm{c}}$ & $0.51 \pm 0.01^{\mathrm{bc}}$ \\
\hline $\mathrm{PRI}_{5}$ & $3.20 \pm 0.14^{\mathrm{d}}$ & $750 \pm 28.5^{\mathrm{d}}$ & $0.65 \pm 0.02^{\mathrm{c}}$ & $0.43 \pm 0.02^{\mathrm{c}}$ \\
\hline $\mathrm{PRI}_{6}$ & $2.42 \pm 0.14^{\mathrm{e}}$ & $650 \pm 32.2^{\mathrm{d}}$ & $0.58 \pm 0.03^{\mathrm{d}}$ & $0.37 \pm 0.01^{\mathrm{d}}$ \\
\hline Control & $3.99 \pm 0.19^{c}$ & $1234 \pm 39.4^{\mathrm{b}}$ & $1.04 \pm 0.04^{\mathrm{a}}$ & $0.55 \pm 0.02^{\mathrm{a}}$ \\
\hline Mean & 3.93 & 1070.9 & 0.81 & 0.51 \\
\hline SE & 0.216 & 77.3 & 0.040 & 0.022 \\
\hline $\mathrm{CD}(0.05)$ & $0.455 * *$ & $162.3^{* *}$ & $0.085^{* *}$ & $0.047^{* *}$ \\
\hline $\mathrm{CD}(0.01)$ & 0.623 & 222.4 & 0.116 & 0.064 \\
\hline
\end{tabular}

Changes in rice root length, surface area, root diameter, and volume are shown at different partial root-zone irrigation treatments. Values indicate the mean of eight plants; \pm indicates standard error of the mean; letters indicate significant differences $(P<0.05)$ among means according to Student's $t$-test. CD represents the critical difference at $95 \%(0.05)$ and $99 \%(0.01)$ confidence limit.

TABle 4: Ratio of the shoot to root, shoot, and root dry of PMK $(R) 3$ rice by split root experiment.

\begin{tabular}{lccc}
\hline Irrigation treatments & Shoot dry mass $(\mathrm{g})$ & Root dry mass $(\mathrm{g})$ & Shoot:root ratio \\
\hline $\mathrm{PRI}_{1}$ & $70.3 \pm 0.63^{\mathrm{c}}$ & $3.9 \pm 0.03^{\mathrm{ab}}$ & $17.8 \pm 0.21^{\mathrm{bc}}$ \\
$\mathrm{PRI}_{2}$ & $74.7 \pm 0.70^{\mathrm{b}}$ & $4.2 \pm 0.10^{\mathrm{a}}$ & $18.0 \pm 0.51^{\mathrm{bc}}$ \\
$\mathrm{PRI}_{3}$ & $85.0 \pm 0.75^{\mathrm{a}}$ & $4.1 \pm 0.05^{\mathrm{a}}$ & $20.5 \pm 0.29^{\mathrm{b}}$ \\
$\mathrm{PRI}_{4}$ & $65.3 \pm 0.59^{\mathrm{de}}$ & $3.2 \pm 0.09^{\mathrm{c}}$ & $20.3 \pm 0.60^{\mathrm{bc}}$ \\
$\mathrm{PRI}_{5}$ & $63.7 \pm 0.68^{\mathrm{e}}$ & $2.6 \pm 0.15^{\mathrm{d}}$ & $24.9 \pm 1.79^{\mathrm{a}}$ \\
$\mathrm{PRI}_{6}$ & $55.4 \pm 0.46^{\mathrm{f}}$ & $2.2 \pm 0.13^{\mathrm{e}}$ & $25.6 \pm 1.51^{\mathrm{a}}$ \\
Control & $66.1 \pm 0.56^{\mathrm{d}}$ & $3.8 \pm 0.11^{\mathrm{b}}$ & $17.5 \pm 0.53^{\mathrm{c}}$ \\
Mean & 68.6 & 3.4 & 20.7 \\
$\mathrm{SE}$ & 0.168 & 0.117 & 1.23 \\
$\mathrm{CD}(0.05)$ & $0.353^{* *}$ & $0.246^{* *}$ & $2.59^{* *}$ \\
$\mathrm{CD}(0.01)$ & 0.484 & 0.337 & 3.54 \\
\hline
\end{tabular}

Values indicate the mean of eight plants; \pm indicates standard error of the mean; letters indicate significant differences $(P<0.05)$ among means according to Student's $t$-test. CD represents the critical difference at $95 \%(0.05)$ and $99 \%(0.01)$ confidence limit. 


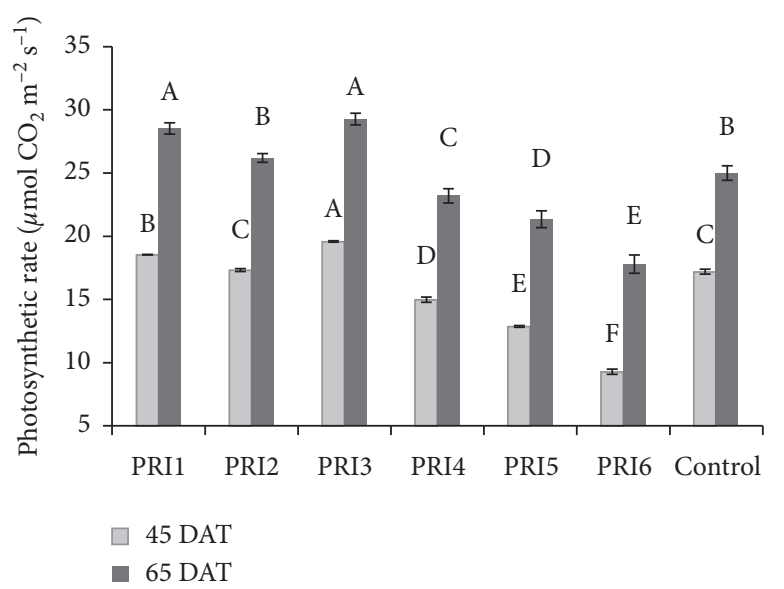

(a)

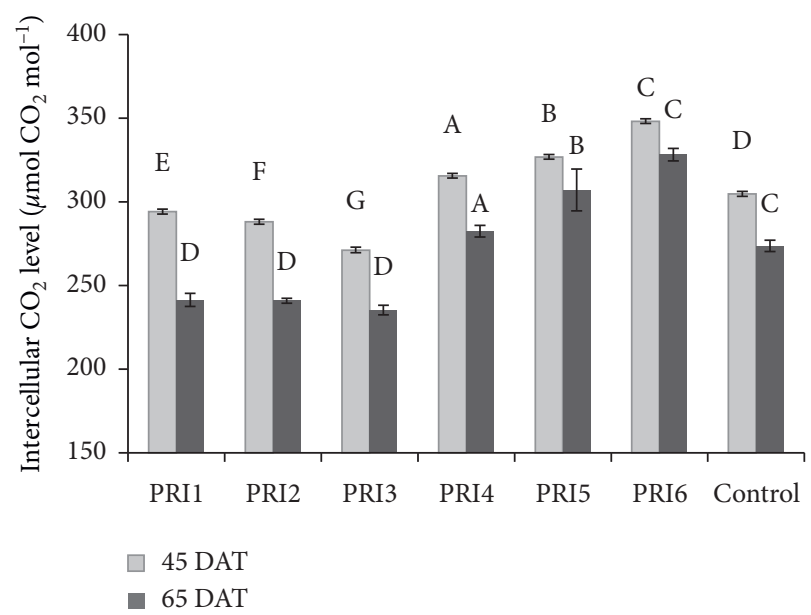

(c)

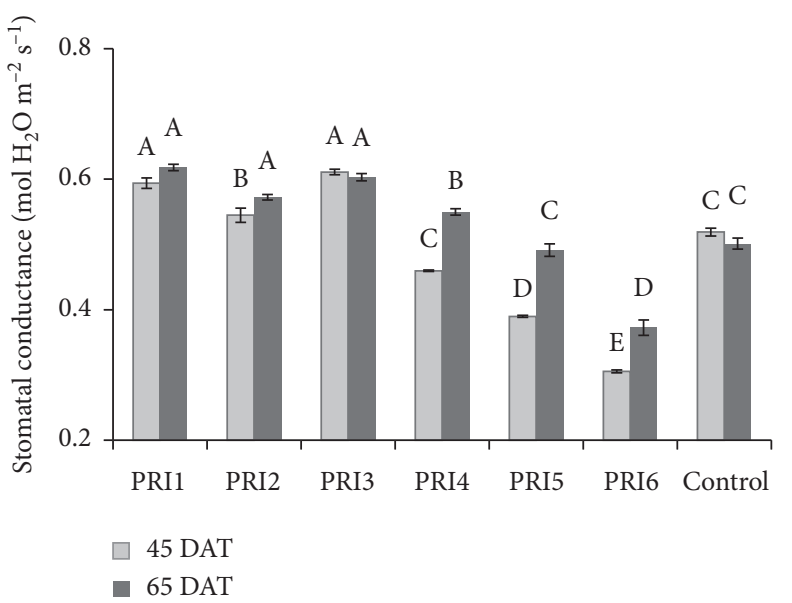

(b)

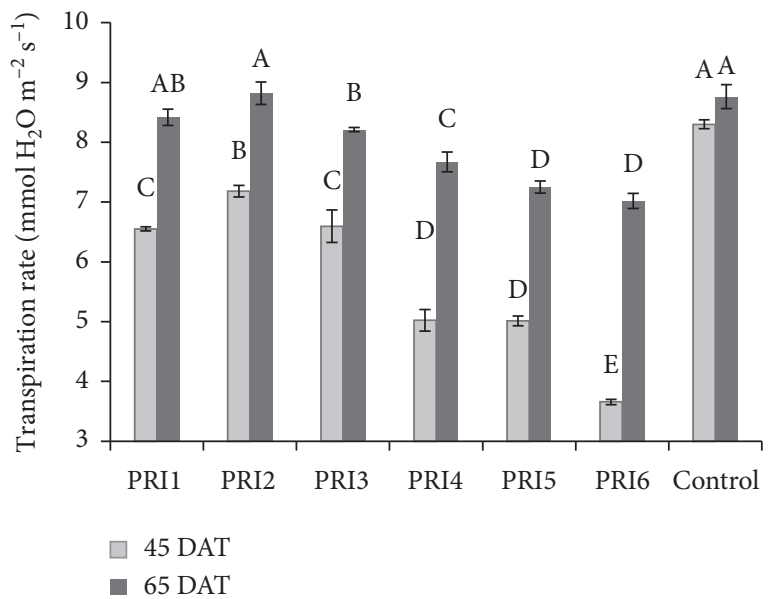

(d)

FIgURE 3: Leaf gas exchange measurements of rice crop under the split root experiment. Changes in leaf photosynthetic rate $\left(P_{\mathrm{N}}\right)(\mathrm{a})$, stomatal conductance $\left(g_{s}\right)(\mathrm{b})$, intercellular $\mathrm{CO}_{2}$ concentration $\left(C_{\mathrm{i}}\right)(\mathrm{c})$, and transpiration rate $\left(T_{\mathrm{r}}\right)(\mathrm{d})$ at different partial root-zone irrigation treatments. Error bars indicate one standard error of the mean. Different letters denote significant differences among means derived using an ANOVA and Student's $t$-test.

average number of panicles was significantly higher in $\mathrm{PRI}_{3}$ treatment. Average spikelet numbers filled grain percentage, and thousand-grain weight was increased by $\mathrm{PRI}_{3}$ treatment over conventional irrigation at $8.4 \%, 2.5 \%$, and $1.7 \%$, respectively. Grain yield increased by $11.0 \%$ in $\mathrm{PRI}_{3}$ treatment $(P=0.05)$ compared to conventional irrigation; however, the yield was comparable in $\mathrm{PRI}_{1}$ and $\mathrm{PRI}_{2}$. Water productivity was significantly increased by $81 \%$ with higher grain yield in the $\mathrm{PRI}_{3}$ treatment than in the conventional irrigation.

\section{Discussion}

Growing rice crops under partial root-zone irrigation (PRI) are being investigated in response to available deficit water resources. In the present study, we have shown that the supply of water to the partial root zone of rice affects growth, leaf gas exchange, water usage, and yield.
The growth response of rice under the partial root-zone irrigation (PRI) method is preferred. Rice grown under PRI on the third day is found taller than the rest and the same PRI practice enhanced the plant growth and tillering ability to improve total dry matter accumulation (root and shoot dry mass) along with the extended photosynthetic surface. This was due to wet and dry cycles that enhanced the aeration between the soil and the atmosphere. Similarly, Pascual and Wang [28] reported that safe alternate wet and dry irrigation produced more tillers and promoted rice growth. Plants were grown under the third day PRI that enhanced the water uptake, resulting in improved leaf elongation rate, and root dry mass contributed to a better shoot to root ratio. This response in rice growth by PRI was supported by Thakur et al. [29], who reported that rice growth was improved under intermittent irrigation. Although the PRI at the sixth-day interval experienced high water demand, this sensitivity reduced the plant height, TDMA, and leaf area. Such demands created water stress to 


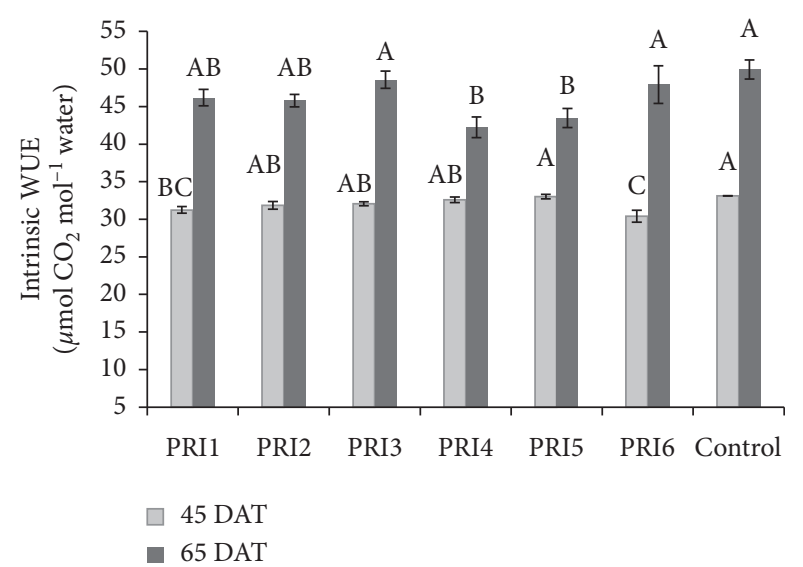

(a)

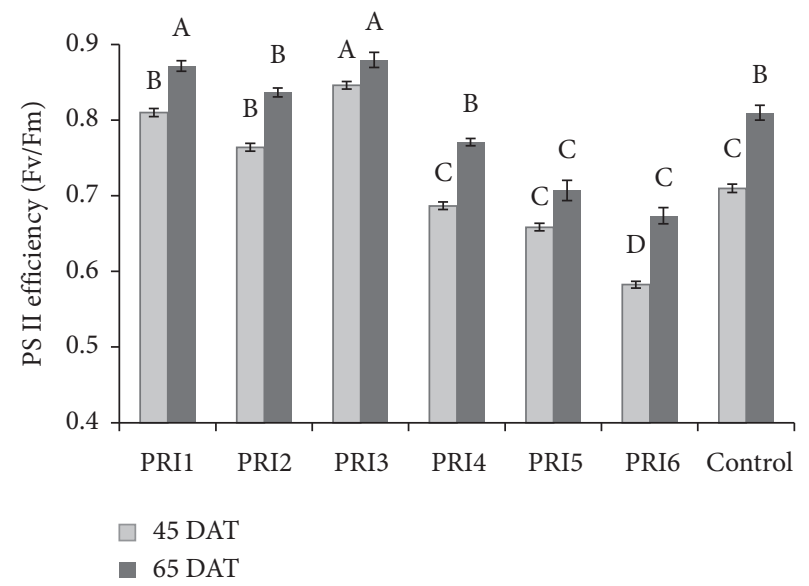

(c)

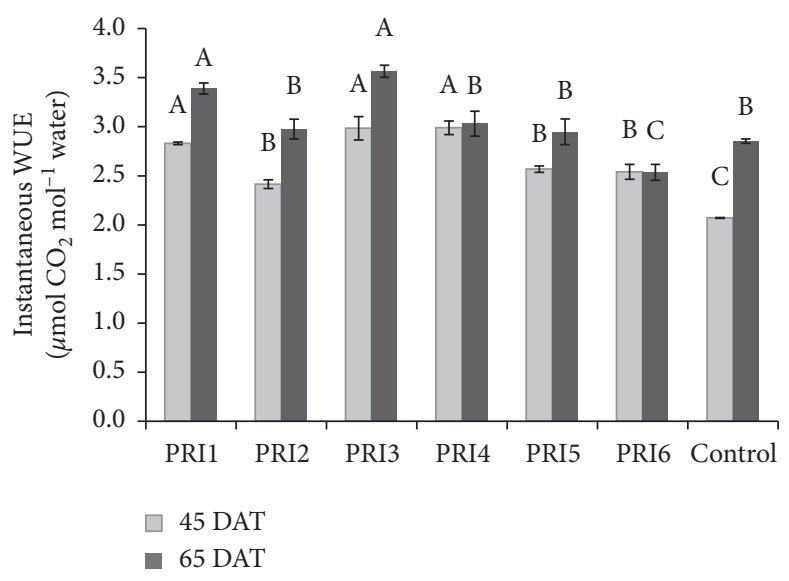

(b)

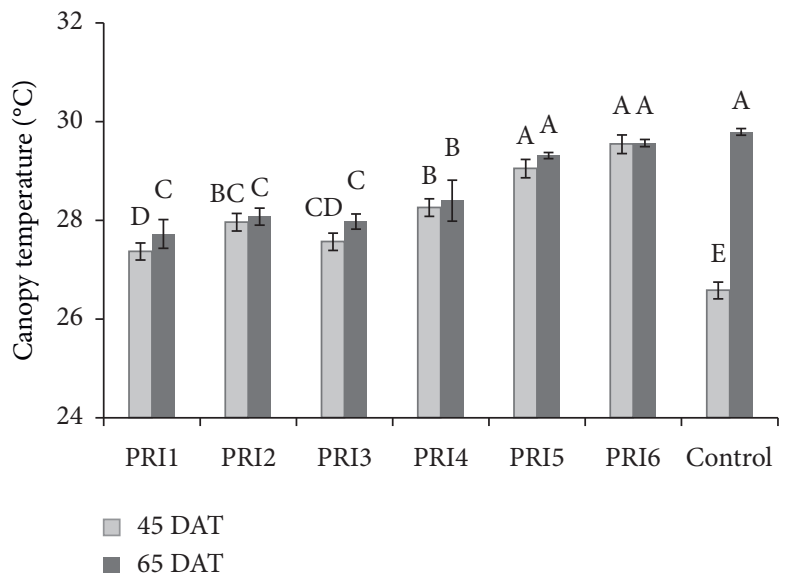

(d)

Figure 4: Leaf water use efficiency, photosystem efficiency, and canopy temperature measurements of rice under the split root experiment. Changes in leaf intrinsic $\left(P_{N} / g_{s}\right)(a)$, instantaneous $\left(P_{N} / T_{r}\right)$, (b) Water Use Efficiency, photosystem efficiency (PS II efficiency) (c), and canopy temperature $(\mathrm{d})$ at different partial root-zone irrigation treatments. Error bars indicate one standard error of the mean. Different letters denote significant differences among means derived using an ANOVA and Student's $t$-test.

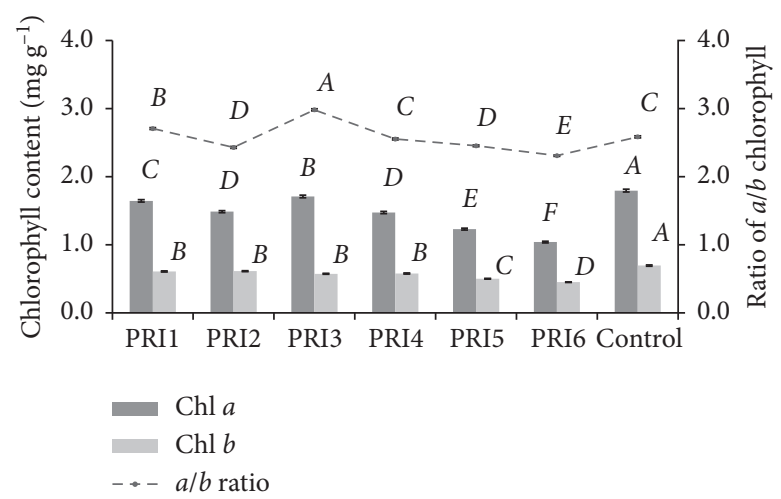

FIGURE 5: Leaf pigment concentrations of PMK (R) 3 rice by split root experiment. Changes in leaf chlorophyll a, b, and a/b ratio at different irrigation treatments. Error bars indicate one standard error of the mean. Different letters denote significant differences among means derived using an ANOVA and Student's $t$-test.

inhibit photosynthesis through reduced cell elongation or cell division, leading to a poor tiller number, which agrees with Akram et al. [30]. The study speculates that PRI improves root growth, which favors other physiological processes leading to higher rice yield and WUE. The effect of PRI is the promotion of increased root growth by depth, and 


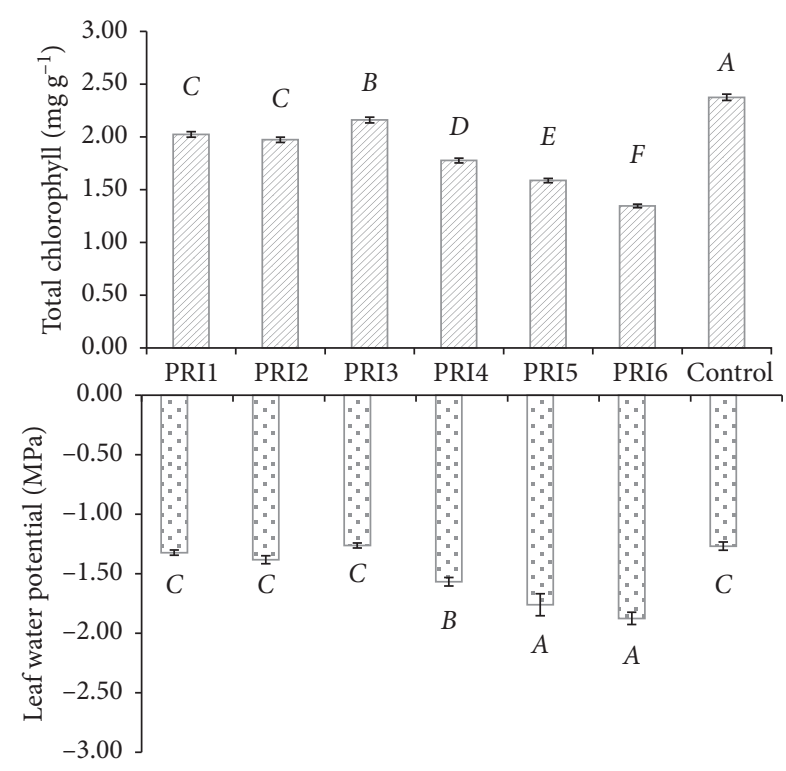

FIGURE 6: Leaf pigment concentration and water potential of PMK (R) 3 rice by split root experiment. Changes in total chlorophyll and leaf water potential at different partial root-zone irrigation treatments during 65 DAT. Error bars indicate one standard error of the mean. Different letters denote significant differences among means derived using an ANOVA and Student's $t$-test.

these results are in line with those of Santos et al. [31] on the root proliferation of grapevine under PRI. Greater root length, root volume at deeper soil layers, and increased root surface area observed in PRI $\left(\mathrm{PRI}_{3}\right)$ could be due to the wet part of the root system experiencing optimal soil moisture, and there is insufficient moisture at the dry side that enhanced the root traits, which corroborates Dodd et al. [8], who reported that the dry side of PRI can maximize abscisic acid hormone export from deeper root systems. Zhang et al. [32] also demonstrated that alternated wetting and drying in rice could enhance root growth and facilitate nutrient assimilation. Repeated wet and dry cycles by PRI enhanced thinner root production through lesser root diameter (Table 3) values, which was favorable for water and nutrient uptake. This is further supported by Parthasarathi et al. [33] who reported that increased root growth and development of the thinner roots help the rice to explore the wider area of soil and the deeper soil layers for water and nutrients. The PRI introduced the plants to moderate stress than under conventional irrigation [13] and resulted in a triggered physiological and biochemical changes in the present study.

Leaf chlorophyll and leaf water potential are important indicators of plant health [34]. Also, changes in chlorophyll $\mathrm{a} / \mathrm{b}$ ratio may be a good indicator of tolerance and physiological status of plants under stress conditions [35]. However, high variability in the levels of photosynthetic pigments in PRI was due to day intervals in wet and dry cycles. Frequent wet and dry irrigation on a one- to threeday interval PRI could not cause significant damage to leaf chloroplasts by the maintenance of better leaf water potential (Figure 6) and constructive change in pigment composition (chlorophyll a, b, a/b ratio) (Figure 5). Moreover, a better balance between chlorophyll synthesis and chlorophyllase activity through short wet and dry cycles might be the reason for the increased total leaf chlorophyll (Figure 6) in $\mathrm{PRI}_{3}$ leaves, which was further supported in a previous study by Parthasarathi et al. [36, 37], who reported that rice chlorophyll content and photosynthesis increased under drip irrigation components.

Partial stomatal closure adversely affected stomatal conductance $\left(g_{s}\right)$ in four- to six-day PRI, thereby significantly limiting the photosynthetic rate $\left(P_{N}\right)$ and transpiration $\left(T_{r}\right)$ (Figure 3.) This is reflected in low water use and higher WUE with high photosystem damage (low PS II efficiency) (Figure 4), and these were in line with Souza et al. [38], who considered this as an important deficit irrigation strategy. The third-day PRI resulted in a significant increase in $P_{N}, T_{r}$, and $g_{s}$, indicating that root signals from the dry side were effective in utilizing the intercellular $\mathrm{CO}_{2}$ concentration (Figure 3). Consequently, the intrinsic water use efficiency $\left(P_{N} / g_{s}\right)$ and instantaneous WUE $\left(P_{N} / T_{r}\right)$ were higher with maintained leaf water potential, canopy temperature, and photosystem efficiency at $\mathrm{PRI}_{3}$ (Figure 4). This might be due to short-interval PRI triggering fractional stomatal closure from the dry side and better photosynthesis with effective water balance from the wet side. Stomatal closure was fractional, and this finding was in agreement with the partial stomatal closure of grape wine [39] and rice [40] under alternate wetting and drying.

The number of panicles, spikelet number, and filled grain percentage were significantly increased in $\mathrm{PRI}_{3}$ (Table 5) due to reduced plant height with better water balance. Effective translocation of assimilates from shoot to panicle enhanced by the enhanced grain-filling percentage and PRI may be one of the reasons for the favorable yield attributes. These were in agreement with the comparative results of Davantgar et al. [41] in rice under water stress. In the present study, PRI at increasing intervals $\left(\mathrm{PRI}_{4}\right.$ to $\mathrm{PRI}_{6}$ ) was more critical to rice yield components, resulting in yield reduction. The threshold irrigation response followed the findings of Akram et al. [30] in water-stressed rice.

In PRI, the rice roots subjected to the dry side will induce chemical signals via stomatal conductance and transpiration, whereas the wet side of the root will maintain better plant water relations [42]. The total water applied to rice was reduced by $36.2 \%$ to $62.5 \%$ under PRI treatment than with conventional irrigation. Alternate wetting on the third day $\left(\mathrm{PRI}_{3}\right)$ improves the water use (54\% saving) with no yield penalty (Table 1). Similarly, no yield loss was reported by Bouman [43] and Linquist et al. [44] by adopting safe alternate wetting and drying in rice.

Overall, the highest water productivity was achieved by $\mathrm{PRI}_{4}$ followed by $\mathrm{PRI}_{3}$ with a significant difference compared to conventional irrigation. Irrigation scheduled at the thirdday PRI $\left(\mathrm{PRI}_{3}\right)$ increased the yield by $12.4 \%$ and water productivity by fourfold, with a significant difference over the control. However, the lowest yield reduction (10.5\%) was obtained in $\mathrm{PRI}_{4}$, indicating that $0.03 \mathrm{~kg}$ of grain was lost to saving one cubic meter of water. This water productivity was fifty percent better than the recent results by Pascual and Wang [45] in rice. 
TABLE 5: Changes in yield, yield attributes, and water productivity of PMK $(R) 3$ rice by split root experiment.

\begin{tabular}{|c|c|c|c|c|c|c|}
\hline $\begin{array}{l}\text { Irrigation } \\
\text { treatments }\end{array}$ & $\begin{array}{l}\text { Panicle number } \\
\text { (no. Plant }^{-1} \text { ) }\end{array}$ & $\begin{array}{l}\text { Spikelet number } \\
\left(\text { no. Plant }{ }^{-1}\right)\end{array}$ & $\begin{array}{l}\text { Filled grain } \\
\text { percentage }\end{array}$ & $\begin{array}{l}1000 \text { grain } \\
\text { weight }(\mathrm{g})\end{array}$ & $\begin{array}{l}\text { Grain yield (g } \\
\text { plant }^{-1} \text { ) }\end{array}$ & $\begin{array}{l}\text { Water productivity (kg } \\
\text { grain } \mathrm{m}^{-3} \text { of water) }\end{array}$ \\
\hline $\mathrm{PRI}_{1}$ & $13 \pm 0.5^{\mathrm{ab}}$ & $1222 \pm 23.7^{\mathrm{a}}$ & $92.8 \pm 0.3^{\mathrm{ab}}$ & $27.3 \pm 0.36^{\mathrm{bc}}$ & $27.1 \pm 0.60^{\mathrm{ab}}$ & $0.69 \pm 0.018^{\mathrm{c}}$ \\
\hline $\mathrm{PRI}_{2}$ & $12 \pm 0.3^{b c}$ & $1171 \pm 26.9^{\mathrm{a}}$ & $90.9 \pm 0.5^{\mathrm{b}}$ & $28.0 \pm 0.34^{\mathrm{ab}}$ & $26.8 \pm 1.26^{\mathrm{abc}}$ & $0.85 \pm 0.040^{\mathrm{b}}$ \\
\hline $\mathrm{PRI}_{3}$ & $14 \pm 0.6^{\mathrm{a}}$ & $1249 \pm 22.5^{\mathrm{a}}$ & $94.2 \pm 1.1^{\mathrm{a}}$ & $28.8 \pm 0.31^{\mathrm{a}}$ & $29.9 \pm 0.79^{\mathrm{a}}$ & $1.18 \pm 0.035^{\mathrm{a}}$ \\
\hline $\mathrm{PRI}_{4}$ & $11 \pm 0.5^{\mathrm{c}}$ & $949 \pm 27.9^{\mathrm{b}}$ & $85.9 \pm 1.2^{\mathrm{c}}$ & $26.4 \pm 0.47^{\mathrm{c}}$ & $23.8 \pm 1.58^{\mathrm{cd}}$ & $1.21 \pm 0.069^{\mathrm{a}}$ \\
\hline $\mathrm{PRI}_{5}$ & $8 \pm 0.4^{\mathrm{d}}$ & $796 \pm 45.2^{c}$ & $83.0 \pm 0.8^{\mathrm{d}}$ & $25.1 \pm 0.36^{\mathrm{d}}$ & $21.9 \pm 1.19^{\mathrm{de}}$ & $1.06 \pm 0.057^{\mathrm{a}}$ \\
\hline $\mathrm{PRI}_{6}$ & $5 \pm 0.5^{\mathrm{e}}$ & $583 \pm 52.8^{\mathrm{d}}$ & $79.7 \pm 0.5^{\mathrm{e}}$ & $23.6 \pm 0.43^{\mathrm{e}}$ & $19.6 \pm 0.63^{\mathrm{e}}$ & $1.03 \pm 0.033^{\mathrm{a}}$ \\
\hline Control & $12 \pm 0.3^{b c}$ & $1144 \pm 48.5^{\mathrm{a}}$ & $91.9 \pm 0.8^{\mathrm{ab}}$ & $28.3 \pm 0.53^{\mathrm{ab}}$ & $26.6 \pm 0.95^{\mathrm{bc}}$ & $0.22 \pm 0.007^{\mathrm{d}}$ \\
\hline Mean & 10 & 1016 & 88.4 & 26.8 & 25.1 & 0.86 \\
\hline S.E. & 0.66 & 56.7 & 1.17 & 0.60 & 1.59 & 0.062 \\
\hline $\mathrm{CD}(0.05)$ & $1.39^{* *}$ & $119.1^{* *}$ & $2.45^{* *}$ & $1.27^{* *}$ & 3.34 & $0.129^{* *}$ \\
\hline $\mathrm{CD}(0.01)$ & 1.90 & 163.1 & 3.35 & 1.74 & $4.58^{*}$ & 0.177 \\
\hline
\end{tabular}

Values indicate the mean of eight plants; \pm indicates standard error of the mean; letters indicate significant differences $(P<0.05)$ among means according to Student's $t$-test. CD represents the critical difference at $95 \%$ (0.05) and $99 \%(0.01)$ confidence limit.

\section{Conclusion}

We analyzed the responses of rice to different partial rootzone irrigation (PRI) treatments. Allowing the PRI to the rice resulted in diverse changes in growth, physiology, and yield at different intervals. Among the short-interval PRI treatments $\left(\mathrm{PRI}_{1}, \mathrm{PRI}_{2}\right.$, and $\left.\mathrm{PRI}_{3}\right), \mathrm{PRI}_{3}$ treatment achieved significantly better water productivity $(P=0.05)$ and higher grain yield $(P=0.01)$ than conventional irrigation. On the sixth day, alternate PRI $\left(\mathrm{PRI}_{6}\right)$ caused severe stress, leading to reduced rice growth and yield (by 26.3\%). Furthermore, the $\mathrm{PRI}_{5}$ and $\mathrm{PRI}_{4}$ treated plants experienced milder stress and showed comparable yield and water productivity with other PRI treatments. The third-day-interval PRI showed a better response in rice, such as optimal growth attributes, favorable root plasticity, altered leaf gas exchange, increased photosystem/pigment efficiency, and improved yield and water productivity. A reduction in root diameter (20.1\%) revealed that $\mathrm{PRI}_{3}$ treatment produced thinner and active roots. Higher leaf photosynthesis $\left(P_{N}\right)$ and transpiration $\left(T_{r}\right)$ observed in the $\mathrm{PRI}_{3}$ indicate a better balance between the water potential and stomatal conductance $\left(g_{s}\right)$. Stomatal conductance of $\mathrm{PRI}_{1}$ to $\mathrm{PRI}_{3}$ treatment found on par revealed that short wet and dry cycles induce better leaf gas exchange with a fractional closure of stomata. Irrigation scheduled at the third-day PRI $\left(\mathrm{PRI}_{3}\right)$ was found to be superior in grain yield by $12.4 \%$ with fourfold higher water productivity compared to the control. Therefore, the $3^{\text {rd }}$-day application of water by PRI may be more suitable for rice production with limited water. Partial root-zone irrigation (PRI) can be achieved by adopting a drip irrigation system to the rice. In this context, combining irrigation with fertigation enhanced the PRI response in water-deficit areas, and such results may be extended to other similar environmental conditions. Preliminary findings were directed toward the development of PRI as a suitable management practice for water-scarcity scenarios.

\section{Data Availability}

Raw data are available from the corresponding author upon request.

\section{Conflicts of Interest}

The authors declare that they have no conflicts of interest.

\section{Acknowledgments}

The authors would like to thank the Vellore Institute of Technology, Vellore, Tamil Nadu, India, for their support during the implementation of this study.

\section{References}

[1] J. Elliott, D. Deryng, C. Müller et al., "Constraints and potentials of future irrigation water availability on agricultural production under climate change," Proceedings of the $\mathrm{Na}$ tional Academy of Sciences, vol. 111, no. 9, pp. 3239-3244, 2014.

[2] V. K. Arora, "Application of a rice growth and water balance model in an irrigated semi-arid subtropical environment," Agricultural Water Management, vol. 83, no. 1-2, pp. 51-57, 2006.

[3] C. R. Jensen, A. Battilani, F. Plauborg et al., "Deficit irrigation based on drought tolerance and root signalling in potatoes and tomatoes," Agricultural Water Management, vol. 98, no. 3, pp. 403-413, 2010.

[4] E. Fereres and M. A. Soriano, "Deficit irrigation for reducing agricultural water use special issue on integrated approaches to sustain and improve plant production under drought stress," Jounal of Experimental Botany, vol. 58, pp. 147-159, 2007.

[5] I. C. Dodd, "Rhizosphere manipulations to maximize crop per drop during deficit irrigation," Journal of Experimental Botany, vol. 60, no. 9, pp. 2454-2459, 2009.

[6] I. C. Dodd, "Soil moisture heterogeneity during deficit irrigation alters root-to-shoot signalling of abscisic acid," Functional Plant Biology, vol. 34, no. 5, pp. 439-448, 2007.

[7] F. Liu, R. Song, X. Zhang et al., "Measurement and modelling of ABA signalling in potato (Solanum tuberosum L.) during partial root-zone drying," Environmental and Experimental Botany, vol. 63, no. 1-3, pp. 385-391, 2008.

[8] I. C. Dodd, G. Egea, and W. J. Davies, "Abscisic acid signalling when soil moisture is heterogeneous: decreased photoperiod sap flow from drying roots limits abscisic acid export to the shoots," Plant, Cell \& Environment, vol. 31, no. 9, pp. 1263-1274, 2008. 
[9] D. M. Mingo, J. C. Theobald, M. A. Bacon, W. J. Davies, and I. C. Dodd, "Biomass allocation in tomato (Lycopersicon esculentum) plants grown under partial rootzone drying: enhancement of root growth," Functional Plant Biology, vol. 31, no. 10, pp. 971-978, 2004.

[10] F. Liu, A. Shahnazari, M. N. Andersen, S.-E. Jacobsen, and C. R. Jensen, "Effects of deficit irrigation (DI) and partial root drying (PRD) on gas exchange, biomass partitioning, and water use efficiency in potato," Scientia Horticulturae, vol. 109, no. 2, pp. 113-117, 2006.

[11] C. Kirda, S. Topcu, H. Kaman et al., "Grain yield response and $\mathrm{N}$-fertiliser recovery of maize under deficit irrigation," Field Crops Research, vol. 93, no. 2-3, pp. 132-141, 2005.

[12] Y. Wang, F. Liu, M. N. Andersen, and C. R. Jensen, "Improved plant nitrogen nutrition contributes to higher water use efficiency in tomatoes under alternate partial root-zone irrigation," Functional Plant Biology, vol. 37, no. 2, pp. 175-182, 2010.

[13] C. Liu, G. H. Rubæk, F. Liu, and M. N. Andersen, "Effect of partial root zone drying and deficit irrigation on nitrogen and phosphorus uptake in potato," Agricultural Water Management, vol. 159, pp. 66-76, 2015.

[14] P. R. Dry, B. Loveys, and H. Düring, "Partial drying of the rootzone of grape. I. Transient changes in shoot growth and gas exchange," Vitis, vol. 39, pp. 3-7, 2000.

[15] J. Wang, H. de Kroon, L. Wang et al., "Root foraging and yield components underlying limited effects of partial root-zone drying on oilseed rape, a crop with an indeterminate growth habit," Plant and Soil, vol. 323, no. 1-2, pp. 163-176, 2009.

[16] T. Hu, S. Kang, F. Li, and J. Zhang, "Effects of partial rootzone irrigation on the nitrogen absorption and utilization of maize," Agricultural Water Management, vol. 96, no. 2, pp. 208-214, 2009.

[17] S. M. Sezen, A. Yazar, and S. Tekin, "Effects of partial root zone drying and deficit irrigation on yield and oil quality of sunflower in a Mediterranean environment," Irrigation and Drainage, vol. 60, no. 4, pp. 499-508, 2011.

[18] J.-j. Zhu, Q. Peng, Y.-l. Liang, X. Wu, and W.-l. Hao, "Leaf gas exchange, chlorophyll fluorescence, and fruit yield in hot pepper (capsicum anmuum L.) grown under different shade and soil moisture during the fruit growth stage," Journal of Integrative Agriculture, vol. 11, no. 6, pp. 927-937, 2012.

[19] A. El-Sadek, "Water use optimisation based on the concept of Partial Rootzone Drying," Ain Shams Engineering Journal, vol. 5, no. 1, pp. 55-62, 2014.

[20] S. Dbara, M. Haworth, G. Emiliani, M. M. Ben, A. GómezCadenas, and M. Centritto, "Partial root-zone drying of olive (Olea europaea var. chetoui) induces reduced yield under field conditions," PLoS One, vol. 11, no. 6, Article ID e0157089, 2016.

[21] M. S. Ribeiro, A. T. Netto, T. R. do Couto et al., "Partial rootzone drying in sugarcane (Saccharum officinarum L.): effects on gas exchange, growth and water use efficiency," Theoretical and Experimental Plant Physiology, vol. 26, no. 34, pp. 251-262, 2014.

[22] F. Li, J. Liang, S. Kang, and J. Zhang, "Benefits of alternate partial root-zone irrigation on growth, water and nitrogen use efficiencies modified by fertilization and soil water status in maize," Plant and Soil, vol. 295, no. 1-2, pp. 279-291, 2007.

[23] R. G. Allen, W. O. Pruitt, J. L. Wright et al., "A recommendation on standardized surface resistance for hourly calculation of reference ETo by the FAO56 Penman-Monteith method," Agricultural Water Management, vol. 81, no. 1-2, pp. 1-22, 2006.
[24] S. von Caemmerer and G. D. Farquhar, "Some relationships between the biochemistry of photosynthesis and the gas exchange of leaves," Planta, vol. 153, no. 4, pp. 376-387, 1981.

[25] C. S. W. Kannan and K. S. Venkataramanan, "Gas exchange characteristics in eucalyptus clones," Indian Journal of Plant Physiology, vol. 15, no. 3, pp. 226-233, 2010.

[26] B. Genty, J.-M. Briantais, and N. R. Baker, "The relationship between the quantum yield of photosynthetic electron transport and quenching of chlorophyll fluorescence," Biochimica et Biophysica Acta (BBA) - General Subjects, vol. 990, no. 1, pp. 87-92, 1989.

[27] S. Yoshida, D. A. Forno, J. H. Cook, and K. A. Gomez, Laboratory Manual for Physiological Studies of Rice, p. 43, IRRI, Philippines, Asia, 1971.

[28] K. A. Gomez and A. A. Gomez, Statistical Procedures for Agriculture Research, John Wiley and Sons, New York, NY, USA, 2nd edition, 1984.

[29] V. J. Pascual and Y. M. Wang, "Impact of water management on rice varieties, yield, and water productivity under the system of rice intensification in southern taiwan," Water, vol. 9, no. 3, pp. 1-15, 2016.

[30] A. K. Thakur, S. Rath, D. U. Patil, and A. Kumar, "Effects on rice plant morphology and physiology of water and associated management practices of the system of rice intensification and their implications for crop performance," Paddy and Water Environment, vol. 9, no. 1, pp. 13-24, 2011.

[31] M. Akram, H. Ali, A. Sattar, A. Rehman, and A. Bibi, "Impact of water deficit stress on various physiological and agronomic traits of three basmati rice (Oryza sativa L) cultivars," Journal Animal and Plant Science, vol. 23, pp. 1415-1423, 2013.

[32] T. Santos, C. M. Lopes, and M. L. Rodrigues, "Partial rootzone drying irrigation affects cluster microclimate improving fruit composition of Moscatel field-grown grapevines," Scientia Horticulture, vol. 112, pp. 321-330, 2007.

[33] H. Zhang, Y. Xue, Z. Wang, J. Yang, and J. Zhang, "An alternate wetting and moderate soil drying regime improves root and shoot growth in rice," Crop Science, vol. 49, no. 6, pp. 2246-2260, 2009.

[34] T. Parthasarathi, K. Vanitha, S. Mohandass, E. Vered, and V. Meenakshi, "Variation in rice root traits assessed by phenotyping under drip irrigation," F1000Research, vol. 6, p. 125, 2017.

[35] C. Mao, W. Ding, Y. Wu et al., "Overexpression of a NACdomain protein promotes shoot branching in rice," New Phytologist, vol. 176, no. 2, pp. 288-298, 2007.

[36] D. Camejo, P. Rodríguez, M. Angeles Morales, J. Miguel Dell'Amico, A. Torrecillas, and J. J. Alarcón, "High temperature effects on photosynthetic activity of two tomato cultivars with different heat susceptibility," Journal of Plant Physiology, vol. 162, no. 3, pp. 281-289, 2005.

[37] T. Parthasarathi, K. Vanitha, S. Mohandass, S. Senthilvel, and E. Vered, "Effects of impulse drip irrigation systems on physiology of aerobic rice," Indian Journal of Plant Physiology, vol. 20, no. 1, pp. 50-56, 2015.

[38] T. Parthasarathi, K. Vanitha, S. Mohandass, and V. Eli, "Rice physiology and water use efficiency under drip irrigation," Agron, vol. 110, no. 6, pp. 1-12, 2018.

[39] C. R. Souza, J. P. Maroco, T. Santos, M. L. Rodrigues, C. Lopes, and J. S. Pereira, "Impact of deficit irrigation on water use efficiency and carbon isotope composition $\left(\delta^{13} \mathrm{C}\right)$ of fieldgrown grapevines under Mediterranean climate," Journal of Experimental Botany, vol. 56, pp. 2163-2172, 2005.

[40] C. R. d. Souza, J. P. Maroco, T. P. d. Santos et al., "Partial rootzone drying: regulation of stomatal aperture and carbon 
assimilation in field-grown grapevines (Vitis vinifera cv. Moscatel)," Functional Plant Biology, vol. 30, no. 6, pp. 653-662, 2003.

[41] H. Zhang, T. Chen, Z. Wang, J. Yang, and J. Zhang, "Involvement of cytokinins in the grain filling of rice under alternate wetting and drying irrigation," Journal of Experimental Botany, vol. 61, no. 13, pp. 3719-3733, 2010.

[42] N. Davantgar, M. R. Neishabouri, A. R. Sepaskhah, and A. Soltani, "Physiological and morphological responses of rice (Oryza sativa L.) to varying water stress management strategies," International Journal of Plant Production, vol. 3, pp. 19-32, 2009.

[43] J. M. Costa, M. F. Ortuño, and M. M. Chaves, "Deficit irrigation as a strategy to save water: physiology and potential application to horticulture," Journal of Integrative Plant Biology, vol. 49, no. 10, pp. 1421-1434, 2007.

[44] B. A. M. Bouman, "A conceptual framework for the improvement of crop water productivity at different spatial scales," Agricultural Systems, vol. 93, no. 1-3, pp. 43-60, 2007.

[45] B. A. Linquist, M. M. Anders, M. A. A. Adviento-Borbe et al., "Reducing greenhouse gas emissions, water use, and grain arsenic levels in rice systems," Global Change Biology, vol. 21, no. 1, pp. 407-417, 2015.

[46] V. J. Pascual and Y.-M. Wang, "Utilizing rainfall and alternate wetting and drying irrigation for high water productivity in irrigated lowland paddy rice in southern Taiwan," Plant Production Science, vol. 20, no. 1, pp. 24-35, 2017. 